\title{
Pengaruh Pakan Bioenkapsulasi Artemia salina dengan Spirulina platensis Terhadap Tingkat Kelangsungan Hidup Benih Ikan Nila (Oreochromis niloticus)
}

\author{
Eko Suyanto ${ }^{1)^{*}}$, Yasir Saifur Rahman ${ }^{2)}$, Murwantoko ${ }^{2)}$ \\ ${ }^{1)}$ Jurusan Biologi, Fakultas Matematika dan Ilmu Pengetahuan Alam, Universitas Brawijaya, Jl Veteran Malang, Jawa \\ Timur, Indonesia \\ ${ }^{2)}$ Departemen Perikanan, Fakultas Pertanian, Universitas Gadjah Mada, Jl. Flora, Bulaksumur, Yogyakarta, Indonesia \\ ${ }^{*}$ Alamat korespondensi : esuyanto31@ub.ac.id
}

\begin{abstract}
ABSTRAK
Permintaan ikan nila (Oreochromis niloticus) semakin meningkat dari tahun ke tahun namun terkendala dalam ketersediaan benih karena tingginya resiko serangan penyakit streptococcosis yang menurunkan kelangsungan hidup (sintasan) benih. Tujuan penelitian ini adalah untuk mengetahui pengaruh pemberian pakan bioenkapsulasi Artemia salina dengan Spirulina platensis terhadap sintasan benih ikan nila yang telah diinjeksi bakteri Streptococcus sp. Artemia salina dibioenkapsulasi melalui pemberian pakan tepung $S$. platensis ukuran 37 mikron selama 5 jam, dipanen lalu disimpan pada suhu $4^{\circ} \mathrm{C}$. Bioenkapsulat dianalisis proksimat meliputi analisis kadar air, kadar protein total, kadar lemak, kadar abu, kadar serat kasar dan kadar karbohidrat sedangkan analisis kadar asam lemak dilakukan menggunakan kromatografi gas. Benih ikan nila diberi perlakuan pakan yaitu bioenkapsulat dan pelet ikan dengan perbandingan variasi 25\%:75\% (BASP1), 50\%:50\% (BASP2), 75\%:25\% (BASP3), 100\%:0\% (BASP4) dan 0\%:100\% (K) lalu diuji tantang dengan bakteri Streptococcus sp konsentrasi $10^{6}$ CFU/mL secara rendaman. Pakan bioenkapsulasi $\boldsymbol{A}$. salina dengan $\boldsymbol{S}$. platensis memberikan pengaruh terhadap tingkat kelangsungan hidup (sintasan) benih ikan nila. Peningkatan sintasan benih terbaik diperoleh pada hari ke-7 sebesar 26,7\% . Pemberian pakan bioenkapsulat dengan konsentrasi $50 \%$ dan $\mathbf{7 5 \%}$ cukup efektif diberikan hingga hari ke14 untuk meningkatkan sintasan benih ikan nila. Semakin tinggi konsentrasi pakan bioenkapsulat dapat meningkatkan resiko kematian benih ikan nila.
\end{abstract}

Kata kunci: streptococcosis, nila, pakan, bioenkapsulat, sintasan

\section{Effect of Bioencapsulated Artemia salina with Spirulina platensis on Survival Rate of Nile Tilapia (Oreochromis niloticus) Juvenile}

\author{
Eko Suyanto $^{1)^{*}}$, Yasir Saifur Rahman ${ }^{2)}$, Murwantoko ${ }^{2)}$ \\ ${ }^{1)}$ Biology Department, Faculty of Mathematics and Natural Sciences, Universitas Brawijaya, Jl Veteran Malang, East
} Java, Indonesia

${ }^{2)}$ Fisheries Department, Faculty of Agriculture, Universitas Gadjah Mada, Jl. Flora, Bulaksumur, Yogyakarta, Indonesia

${ }^{*}$ Email: esuyanto31@ub.ac.id

\begin{abstract}
The demand for tilapia (Oreochromis niloticus) is increasing significantly but constrained in the juvenile availability due to the high risk of streptococcosis disease, which reduces of juvenile survival rates. Herein, we reported the study about effect of feed on fish. The aim of study was determined effect of bioencapsulated Artemia salina with Spirulina platensis on survival rate of tilapia juvenile after injected by Streptococcus sp. Bioencapsulation of $A$. salina with $S$. platensis was carried out by feeding of $S$. platensis $37 \mu \mathrm{m}$ size into $A$. salina for 5 hours, harvested and then stored at $4^{\circ} \mathrm{C}$. It was analyzed by proximate including water content, total protein, fat, ash, crude fiber and carbohydrate while fatty acid levels was analyzed using gas chromatography. The study was designed using 5 treatments and triplicates of tilapia juvenile feed (bioencapsulation product and fish pellet) with ratio of 25\%: 75\% (BASP1), 50\%: 50\% (BASP2), 75\%: $25 \%$ (BASP3), 100\%: 0\% (BASP4) and $0 \%: 100 \%(\mathrm{~K})$ then challenge test with concentration of bacteria was $10^{6}$ CFU/mL by immersion. The feed of bioencapsulated $A$. salina with $S$. platensis has influenced on the survival
\end{abstract}


rate of tilapia juvenile. The best improvement of survival rate was obtained on the $7^{\text {th }}$ day by $26.7 \%$. Fish feed with concentration of $50-75 \%$ is effective until the $14^{\text {th }}$ day to increase tilapia juvenile survival rate. The higher concentration of feed will increase the risk of death of tilapia juvenile.

Keywords: streptococcosis, tilapia, feed, bioencapsulation, survival rate

\section{PENDAHULUAN}

Ikan nila (Oreochromis niloticus) merupakan ikan introduksi yang populer menjadi ikan konsumsi di Indonesia karena nilai ekonomi dan nilai gizi yang tinggi serta memiliki keunggulan antara lain, mudah dipijahkan, kemampuan tumbuh yang cepat, mampu mencerna makanan yang tinggi karbohidrat, dapat diberi pakan alami maupun pakan buatan, toleransi luas terhadap perubahan lingkungan, serta memiliki daya tahan yang baik terhadap serangan penyakit. Berbagai kelebihan yang dimiliki menjadikan ikan nila mendapat perhatian cukup besar dari pemerintah dan pemerhati masalah perikanan berkaitan dengan usaha peningkatan produksi dan gizi masyarakat di negara yang sedang berkembang. Produksi ikan nila di Indonesia pada tahun 2010 hanya sebesar 469.173 ton sedangkan pada tahun 2011 meningkat 36,26\% dari tahun sebelumnya. Pada tahun 2013, produksi ikan nila mencapai sekitar 1,1 juta ton $[1,2]$. Kenyataan ini menunjukkan bahwa setiap tahun permintaan pasar domestik maupun luar negeri terhadap ikan nila yakni ikan segar maupun dalam bentuk fillet semakin meningkat sehingga pemerintah Indonesia berupaya meningkatkan produksinya namun upaya ini seringkali terkendala dalam budidaya ikan nila $[1,3]$. Salah satu kendala utama dalam pengembangan budidaya ikan nila di Indonesia adalah kurangnya ketersediaan benih di tingkat pembenihan yaitu kualitas benih yang dihasilkan dan kuantitas pasokan benih yang masih rendah. Padahal kebutuhan pasar terhadap ikan nila tidak hanya terbuka untuk ikan nila yang berukuran konsumsi namun juga ikan nila pada stadium benih. Sebagai perbandingan, setiap bulannya benih ikan yang dibutuhkan sekitar 14 juta ekor namun baru terpenuhi 2,5-3 juta ekor [2,4].

Fase larva dan benih merupakan masa paling kritis dalam siklus hidup ikan. Masamasa kritis ditandai dengan tingginya angka kematian (mortalitas) dan tingginya serangan penyakit. Salah satu penyakit yang sering menyerang ikan nila adalah streptococcosis, disebabkan oleh bakteri Streptococcus sp yang menyebabkan kerugian sekitar 30-40\%. Terdapat beberapa jenis bakteri Streptococcus yang diketahui menginfeksi ikan nila yaitu $S$. iniae dan $S$. dysgalactiae [5]. Namun beberapa tahun terakhir, ditemukan $S$. agalactiae yang menginfeksi ikan nila [6] dan menyebabkan kematian ikan nila setelah 24-48 jam setelah infeksi [7]. Bakteri ini menyerang ikan pada perairan umum maupun pada ikan budidaya yang menyebabkan kerusakan organ ikan sehingga berakibat pada kematian ikan hingga $100 \%$ pada ikan budidaya [8].

Salah satu upaya yang sering dilakukan untuk mengendalikan penyakit ini adalah pemberian antibiotik. Namun pemakaian antibiotik secara terus menerus berdampak pada resistensi bakteri dan adanya isu mengenai keamanan pangan serta keamanan lingkungan. Dalam penelitian ini, melihat perspektif lain dalam upaya mengatasi penyakit streptococcosis yaitu dengan meningkatkan imunitas ikan pada tahap pembenihan melalui pemberian pakan alami. Pakan alami potensial adalah Artemia salina yang dapat memakan berbagai macam sesuai ukuran mulut. Disisi lain, Spirulina platensis mengandung protein tinggi serta berbagai jenis vitamin. Selain itu juga mengandung fikosianin hingga mencapai $20 \%$ dari bobot keringnya yang diketahui berperan penting dalam sistem imunitas, antioksidan, antiinflamasi dan neuroprotektif [9]. Namun, $S$. platensis secara langsung sulit dimakan oleh benih ikan. Oleh karena itu, kandungan gizi terutama fikosianin pada $S$. platensis berpotensi disisipkan ke dalam $A$. salina melalui bioenkapsulasi sehingga nilai gizinya semakin tinggi.

Pakan alami tersebut mampu menarik benih ikan untuk membiasakan menelan pakan dari luar tubuhnya. Selain itu pakan alami juga memiliki bentuk dan ukuran sesuai dengan lebar bukaan mulut benih ikan sehingga pemberian pakan lebih efektif dan efisien. Tujuan penelitian ini adalah untuk mengetahui pengaruh pemberian pakan bioenkapsulasi Artemia salina dengan Spirulina platensis terhadap tingkat 
kelangsungan hidup (sintasan) benih ikan nila yang telah diinjeksi bakteri Streptococcus sp.

\section{METODE PENELITIAN}

Pemeliharaan dan penepungan. Penelitian dilakukan di Balai Besar Perikanan Budidaya Air Payau, Jepara dan Laboratorium Basah BDP Fakultas Pertanian UGM. Telur Artemia salina ditetaskan secara dekapsulasi kemudian dipelihara dengan kultur standar melalui pemberian pakan berupa silase ikan dan tepung tapioka. Setelah berumur 14 hari populasi $A$. salina dipadatkan dengan kepadatan \pm 5000 ekor/L lalu dipuasakan selama 24 jam [10]. Kultur Spirulina platensis yang telah dipelihara lalu dipanen. Penepungan $S$. platensis dilakukan dengan cara menghilangkan kandungan air melalui pemanasan pada suhu $60^{\circ} \mathrm{C}$ kemudian digerus dan disaring hingga diperoleh ukuran 37 mikron [11].

Bioenkapsulasi. Kultur A. salina yang telah dipuasakan diberi pakan tepung $S$. platensis 37 mikron sebanyak $100 \mathrm{mg} / \mathrm{L}$. Setelah 5 jam dilakukan pengecekan sistem digesti untuk memastikan tepung $S$. platensis sudah dikonsumsi secara optimal oleh $A$. salina lalu dipanen menggunakan plankton net. Biomassa A. salina dibilas dengan air laut steril untuk menghilangkan kotoran lalu disimpan pada suhu $4^{\circ} \mathrm{C}$ [12].

Analisis proksimat dan asam lemak. Analisis kandungan gizi bioenkapsulat dilakukan dengan melakukan analisis proksimat meliputi kadar air, kadar protein total, kadar lemak, kadar abu, kadar serat kasar dan kadar karbohidrat [13]. Analisis kadar asam lemak dilakukan dengan cara transesterifikasi in situ [14] lalu dianalisis menggunakan gas chromatography.

Pemeliharaan dan perlakuan. Benih ikan Nila Saline (Oreochromis niloticus) usia 3 minggu dengan ukuran panjang 2,5-3 cm diaklimatisasi selama 10 hari. Benih ikan Nila Saline dipelihara dalam bak volume $3 \mathrm{~L}$ yang telah didesinfeksi lalu diisi air tawar, masingmasing bak diisi 10 ekor benih ikan Nila Saline. Aerasi dilakukan secara berkesinambungan dan penggantian air 20$30 \%$ setelah terlihat kotoran bersamaan dengan penyiponan feses dan sisa pakan. Perlakuan pakan yang diberikan yaitu bioenkapsulat dan pelet ikan dengan perbandingan variasi 25\%:75\% (BASP1), 50\%:50\% (BASP2),
75\%:25\% (BASP3), 100\%:0\% (BASP4) dan 0\%:100\% (K) tiap 100 gr. Jumlah ransum pakan sebanyak 3\% dari total berat benih ikan per hari. Frekuensi pemberian pakan dilakukan sebanyak 3 kali sehari. Pemeliharaan benih dengan perlakuan variasi pakan dilakukan selama 20 hari.

Challenge test. Uji tantang (challenge test) terhadap benih ikan nila yang telah diberi perlakuan pakan dilakukan menggunakan Rancangan Acak Lengkap dengan 5 perlakuan dan 3 ulangan. Bakteri Streptococcus sp ditumbuhkan pada $10 \mathrm{~mL}$ medium Nutrient Broth lalu diinkubasi pada suhu $37^{\circ} \mathrm{C}$ selama 24 jam. Kultur cair bakteri dengan kepadatan $10^{6} \mathrm{CFU} / \mathrm{mL}$ diinfeksikan ke dalam media pemeliharaan secara rendaman. Pengamatan dan penghitungan terhadap jumlah benih ikan yang mati dan hidup dilakukan setelah 7 hari dan 14 hari sejak awal infeksi. Jumlah ikan yang masih hidup dari hasil uji tantang digunakan sebagai nilai sintasan benih (survival rate) [15].

\section{HASIL DAN PEMBAHASAN}

Fase larva dan benih merupakan masa kritis dalam siklus hidup ikan karena rentan dengan serangan penyakit maupun terbatasnya ketersediaan pakan sehingga meningkatkan kematian. Benih ikan memerlukan pakan yang sesuai dengan ukuran bukaan mulutnya sehingga ukuran dan kualitas pakan menjadi salah satu faktor yang menentukan kehidupan benih ikan. Dalam penelitian ini perlakuan pakan berupa bioenkapsulasi $A$. salina dengan $S$. platensis merupakan terobosan baru untuk meningkatkan kualitas pakan. Bioenkapsulasi merupakan proses penyisipan nutrien atau obat ke dalam organisme hidup yang kemudian diberikan sebagai pakan pada hewan target. Organisme yang berperan sebagai pembawa nutrien dalam penelitian ini adalah A. salina sedangkan $S$. platensis adalah organisme yang mengandung nutrien target.

Kandungan gizi bioenkapsulat. Hasil analisis proksimat menunjukkan bahwa kandungan air cukup tinggi sebesar 91,1226\% dibanding kandungan senyawa lain seperti protein, lemak dan karbohidrat. Hal ini karena saat pengujian bioenkapsulat dalam kondisi beku dan belum dikeringkan setelah diambil dari freezer. Namun yang perlu dicermati adalah kandungan protein yang cukup tinggi sebesar 3,64977\% dibandingkan senyawa lain (Tabel 1). Kandungan protein yang cukup tinggi ditunjang dengan adanya kandungan pigmen fikosianin diketahui mampu meningkatkan sistem kekebalan 
tubuh, berperan sebagai antioksidan, antiinflamasi serta neuroprotektif [16]. Kandungan kimia ini membantu dalam pertumbuhan benih ikan nila dan mempercepat proses pembentukan otot, organ internal dan tulang. Protein merupakan sumber asam amino esensial dan penyedia nitrogen untuk sintesis asam amino non esensial. Protein yang terdiri dari asam amino yang lengkap dan dalam jumlah seimbang untuk pembentukan jaringan disebut sebagai protein yang berkualitas tinggi. Pertumbuhan ikan berhubungan erat dengan kandungan protein pakan yang disediakan. Pertumbuhan yang tinggi dapat dicapai dengan syarat bahwa protein dalam pakan mempunyai kualitas yang baik, yaitu mempunyai kandungan asam amino yang lengkap dalam jumlah yang memadai. Kandungan asam amino yang ada pada $S$. platensis hampir mendekati sempurna yaitu mengandung 8 macam asam amino essensial antara lain isoleusin, leusin, lysin, methionin, phenilalanin, threonin, trypthopan dan valin [11]. Dengan demikian, kandungan protein dalam A. salina yang diperkaya $S$. platensis mempunyai kualitas dan kuantitas yang tinggi sehingga diharapkan dapat mengoptimalkan sintasan benih ikan nila dari serangan penyakit streptococcosis.

Tabel 1. Kandungan gizi dalam A. salina yang diperkaya dengan S. platensis.

\begin{tabular}{ll}
\hline \multicolumn{1}{c}{ Kandungan } & \multicolumn{1}{c}{ Presentase (\%) } \\
\hline Protein & 3,64977 \\
Karbohidrat & 1,0507 \\
Lemak & 0,41210 \\
Kadar Abu & 2,9989 \\
Kadar air & 91,1226 \\
Serat & 0,7780 \\
\hline
\end{tabular}

Kandungan asam lemak. Pada umumnya lemak yang dibutuhkan oleh ikan dengan bobot di bawah 2 gr adalah sekitar $10 \%$. Berdasarkan hasil uji kandungan asam lemak pada bioenkapsulat menunjukkan bahwa kandungan tertinggi adalah asam stearat sebesar 30,10095\% dari berat total sedangkan yang terendah adalah asam laurat sebesar $2,0302 \%$ (Tabel 2). Terdapat 7 macam asam lemak dari hasil pengujian, hal ini berarti bahwa kandungan asam lemak dalam $A$. salina yang diberi pakan $S$. platensis sudah dapat memenuhi kebutuhan asam lemak benih ikan. Lemak tersusun atas asam-asam lemak yang merupakan salah satu faktor penentu keberhasilan untuk peningkatan pertumbuhan dan kelangsungan hidup ikan.

Tabel 2. Kandungan asam lemak dalam $A$. salina yang diperkaya dengan $S$. platensis.

\begin{tabular}{ll}
\hline \multicolumn{1}{c}{ Kandungan } & \multicolumn{1}{c}{ Presentase (\%) } \\
\hline Asam laurat & 2,0302 \\
Miristic acid & 15,505 \\
Palmitoleic acid & 7,497 \\
Asam stearat & 30,1009 \\
Oleic acid & 13,1330 \\
Linoleic acid & 2,8180 \\
EPA & 4,507 \\
\hline
\end{tabular}

Artemia salina adalah udang renik yang bersifat non-selective filter feeder sehingga kandungan asam lemak pada artemia sangat dipengaruhi oleh pakan yang diberikan. Salah satu asam lemak yang terpenting bagi ikan adalah asam linoleat dan EPA. Kebutuhan asam lemak ini pada ikan nila adalah $0,5 \%$ [17]. Hal ini didukung dengan kebutuhan larva dan benih ikan yang membutuhkan asam lemak ini agar dapat bermetamorfosis secara normal dan lulus hidup [18]. Ikan air tawar membutuhkan asam lemak ini sebagai asam lemak esensial. EPA dan DHA penting untuk pembentukan membran, osmoregulasi, sintesis prostaglandin dan berperan aktif dalam sistem kekebalan tubuh larva ikan [19].

Bioenkapsulasi yang dilakukan dalam penelitian ini dimaksudkan untuk meningkatkan kualitas pakan benih ikan nila sehingga diharapkan dapat mengoptimalkan pertumbuhan dan meningkatkan prosentase sintasan benih. Benih yang dipelihara selama 7 hari dengan pakan A. salina. dengan $S$. platensis diuji tantang dengan bakteri Streptococcus sp secara rendaman untuk mengetahui adanya pengaruh pemberian pakan. Pemberian secara rendaman akan menyebabkan lingkungan air tercemar bakteri sehingga akan menyebabkan infeksi pada ikan nila. Dengan tambahan pakan tadi akan dapat diketahui efektifitas pemberian pakan untuk meningkatkan kelangsungan hidup benih ikan nila terhadap serangan bakteri Streptococcus sp.A

Kelangsungan hidup benih ikan nila. Hasil menunjukkan bahwa benih ikan nila yang telah diberi pakan bioenkapsulasi Spirulina platensis setelah hari ke-7 menunjukkan kemampuan hidup yang berbeda-beda setelah di uji tantang. Benih ikan nila yang masih hidup dijumpai paling banyak pada BASP 4 (Gambar 1). 


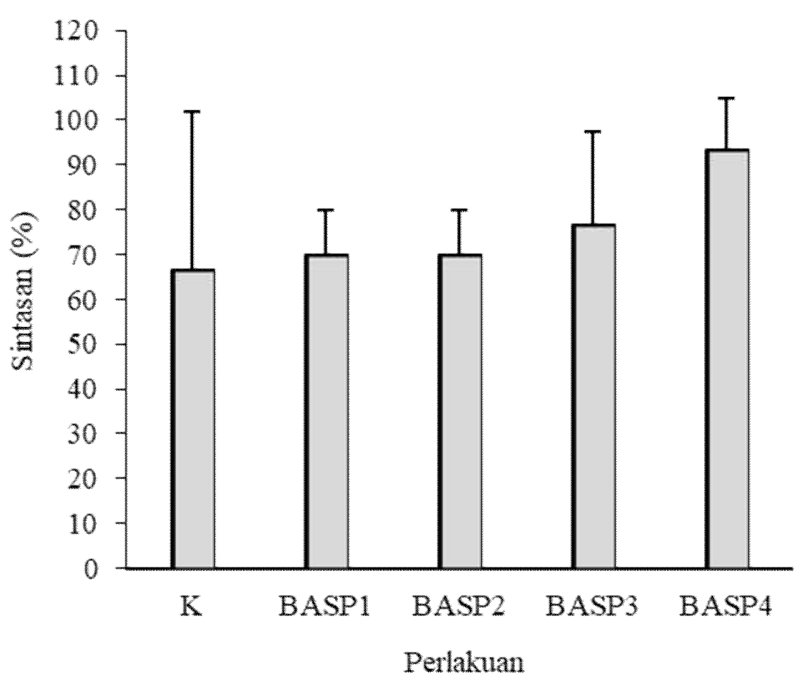

Gambar 1. Tingkat kelangsungan hidup (sintasan) benih ikan nila tiap perlakuan pada hari ke-7.

Selama 7 hari pemeliharaan dalam keadaan terinfeksi oleh bakteri, benih ikan nila yang telah diberikan perlakuan pakan bioenkapsulat masih bisa bertahan hidup, hanya sedikit yang mengalami kematian. Dalam keadaan ini, semakin tinggi konsentrasi pakan bioenkapsulat maka semakin tinggi pula kelangsungan hidup benih ikan nila. Tingkat kelangsungan hidup benih ikan nila yang terinfeksi bakteri diperolah pada perlakukan BASP4 sebesar 93,3\%. Pemberian bioenkapsulat secara signifikan terbukti mampu meningkatkan kelangsungan hidup benih ikan nila dibanding perlakuan kontrol. Hal ini menunjukkan bahwa kandungan gizi yang terdapat pada bioenkapsulat memberikan pengaruh yang signifikasn terhadap daya tahan benih ikan nila dari serangan bakteri Streptococcus yang ditunjukkan dengan jumlah kelangsungan hidup benih ikan nila seiring dengan peningkatan konsentrasi bioenkapsulat. Serangan bakteri ini dapat menyebabkan kematian setela 6-48 jam pascainjeksi. Gejala klinis ikan nila yang terinfeksi bakteri dan memiliki tingkat ketahanan rendah lebih cepat muncul dengan ciri perubahan pola renang, perubahan pada mata, dan respon terhadap pakan [7].

Bakteri patogen ini dapat menginfeksi benih ikan karena memiliki faktor virulensi untuk menginfeksi inang yaitu extracellular product (ECP) yang terdiri dari kapsular polisakarida, protein permukaan dan beberapa sekresi protein [20]. Diduga faktor virulensi inilah yang membantu bakteri menempel pada sel epitel inang untuk menghindari mekanisme pertahanan tubuh inang [21]. ECP bersifat imunogenik pada proses intraseluler, merusak komponen membran atau neurotransmitter [22]. Terdapat 2 macam tipe ECP yaitu tipe non hemolitik diduga sebagai tipe yang lebih virulen dibanding tipe hemolitik karena konsentrasi protein pada ECP-nya lebih tinggi yaitu 13,64 ppm sedangkan tipe hemolitik 8,18 ppm [7].

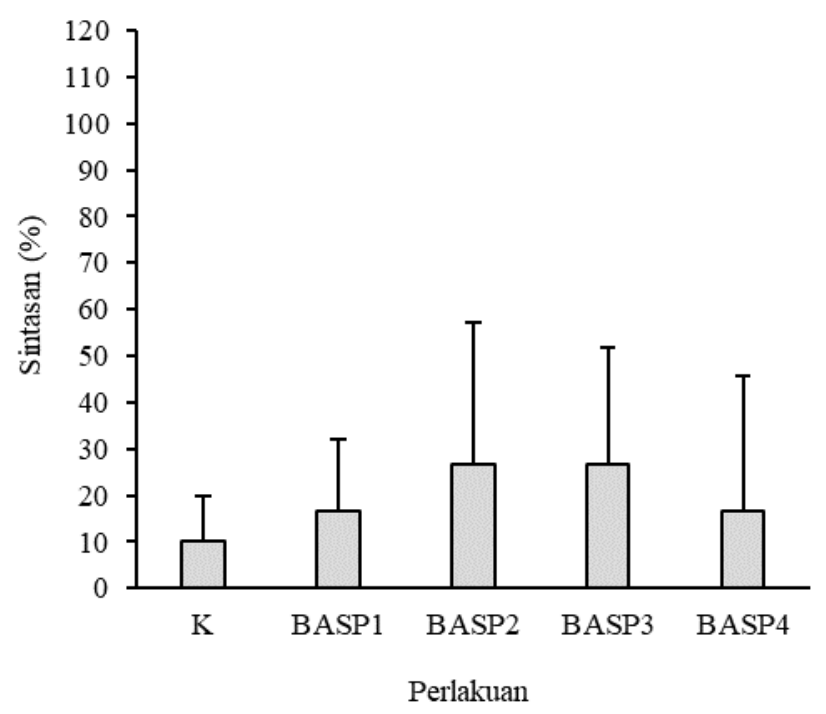

Gambar 2. Tingkat kelangsungan hidup (sintasan) benih ikan nila tiap perlakuan pada hari ke-14.

Semakin lama waktu infeksi bakteri pada benih ikan nilai rupanya menurunkan sistem imun benih ikan nila sehingga berdampak pada tingginya kematian benih ikan nila. Tabel 2 dan Gambar 3 menunjukkan fenomena tersebut yaitu tingkat kelangsungan hidup benih ikan nila untuk semua perlakukan setelah 14 hari infeksi mengalami penurunan. Penurunan kelangsungan hidup ikan nila paling tinggi pada perlakukan control yang hanya memiliki tingkat kelangsungan hidup sebesar 10\%. Kondisi optimum diperoleh pada perlakuan BASP2 dan BASP3 memiliki tingkat kelangsungan hidup benih sebesar 26,6\%. Semakin lama infeksi bakteri pada benih ikan nila akan meningkatkan mortality rate akibat rusaknya sel limfosit sehingga tidak bisa memberikan respon imun pada tubuh ikan [23]. 


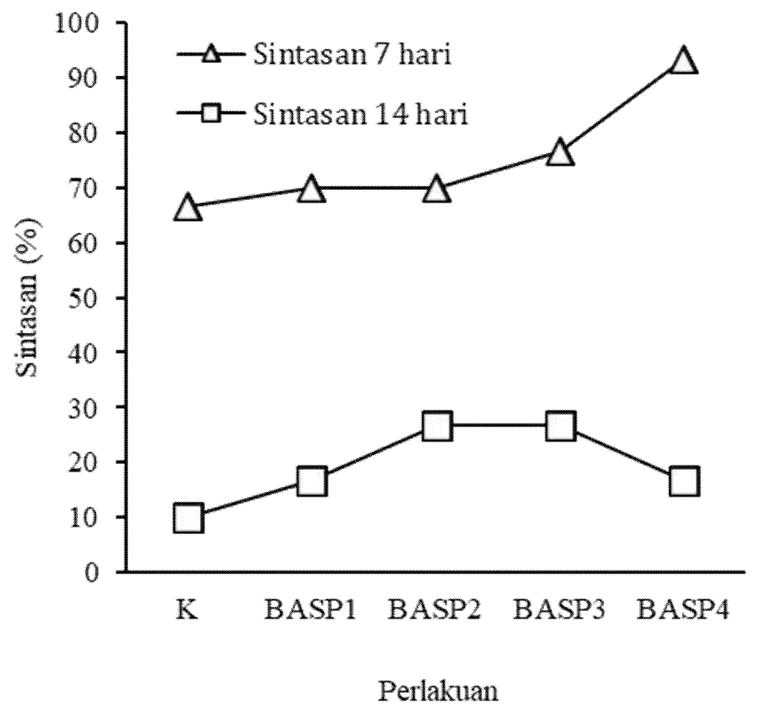

Gambar 3.Hubungan tingkat kelangsungan hidup (sintasan) benih ikan nila tiap perlakuan pada hari ke-7 dan ke-14.

Analisa statistik menggunakan RAL menunjukkan tidak terdapat beda nyata antara ke-5 perlakuan setelah 14 hari perlakuan. Hal ini berarti bahwa dengan pemberian pakan bioenkapsulat pada benih ikan nila yang telah diuji tantang dengan bakteri Streptococcus sp penyebab penyakit streptococcosis tidak memberikan pengaruh terhadap kelangsungan hidup ikan nila pada hari ke-14. Tidak adanya pengaruh tersebut karena tingkat infeksi bakteri tinggi dan kerusakan limposit sebagaimana dijelaskan sebelumnya. Gambar 3 menjelaskan hubungan kontradiktif kondisi kelangsungan hidup benih ikan pada hari ke-7 dan hari ke-14 dimana pemberian pakan bioenkapsulat dengan konsentrasi tinggi pada benih ikan nila setelah hari ke-14 menurunkan sintasan benih ikan nila yang berlawanan dengan sintasan benih ikan nila setelah hari ke7. Diperkirakan hal ini masih berkaitan dengan kerusakan limfosit dan adanya ketidakseimbangan nutrien dalam tubuh ikan karena kandungan protein yang tinggi. Kandungan protein yang tinggi akan menyebabkan deaminasi asam amino yang membutuhkan banyak energi. Energi yang seharusnya digunakan untuk pertumbuhan dan perbaikan jaringan akibat kerusakan limfosit oleh adanya infeksi bakteri digunakan untuk deaminasi asam amino dan diekskresikan sebelum digunakan untuk pertumbuhan. Dalam keadaan terinfeksi bakteri, ikan akan membutuhkan energi untuk meningkatkan ketahanan tubuhnya. Tetapi kebutuhan energi itu tidak terpenuhi secara optimal karena energi telah habis untuk deaminasi asam amino. Saat ketahanan tubuh ikan lemah, ikan menjadi mudah stress dan terserang penyakit yang akhirnya berujung pada kematian.

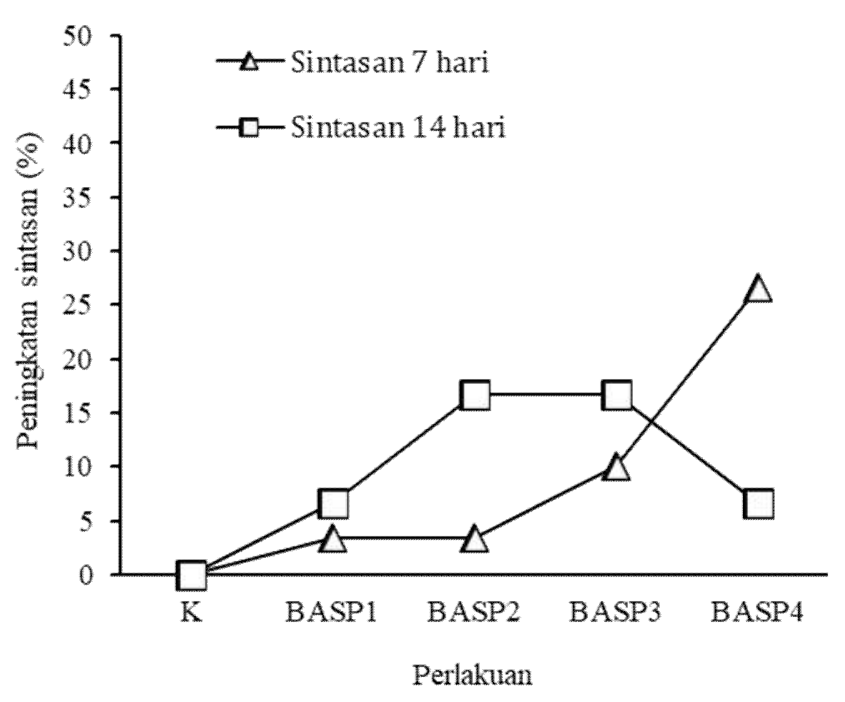

Gambar 4. Peningkatan kelangsungan hidup (sintasan) benih ikan nila tiap perlakuan pada hari ke-7 dan ke-14

Deaminasi akan menghasilkan amonia dan senyawa karbon yang dikeluarkan melalui insang dan ginjal [24]. Jika protein yang dikonsumsi ikan terlalu tinggi maka buangan ammonia akan tinggi. Kandungan buangan amonia yang tinggi dalam air tempat ikan hidup bersifat toksik dan dapat meningkatkan stres pada ikan. Saat ikan stres maka pertumbuhannya akan terganggu dan menjadi mudah terserang oleh penyakit. Jadi tinggi rendahnya sintasan seiring dengan tinggi rendahnya pertumbuhan.

Walaupun sintasan benih ikan nila cenderung menurun namun terdapat peningkatan sintasan benih ikan nila bila dibandingkan dengan kontrol (Gambar 4). Peningkatan sintasan terbaik diperoleh pada hari ke-7 untuk perlakuan BASP4 sebesar $26,7 \%$ sedangkan pada hari ke-14 kondisi optimum peningkatan sintasan diperoleh pada perlakuan BASP2 dan BASP3 sebesar 16,7\%.

\section{KESIMPULAN}

Pakan bioenkapsulasi A. salina dengan $S$. platensis memberikan pengaruh terhadap tingkat kelangsungan hidup benih ikan nila. Peningkatan kelangsungan hidup terbaik diperoleh pada hari ke-7 sebesar 26,7\%. Pemberian pakan 
bioenkapsulat dengan konsentrasi 50-75\% cukup efektif diberikan hingga hari ke-14. Semakin tinggi konsentrasi pakan bioenkapsulat akan meningkatkan resiko kematian benih ikan nila.

\section{UCAPAN TERIMA KASIH}

Penulis mengucapkan terimakasih kepada Kementerian Riset, Teknologi, dan Pendidikan Tinggi Republik Indonesia atas bantuan dana untuk melaksanakan kegiatan penelitian ini.

\section{DAFTAR PUSTAKA}

[1] Ihsanuddin I, Rejeki S, Yuniarti T (2014) Pengaruh pemberian rekombinan hormon pertumbuhan $(r G H)$ melalui metode oral dengan interval waktu yang berbeda terhadap pertumbuhan dan kelulushidupan benih ikan Nila Larasati. Journal of Aquaculture Management and Technology 3 (2): 94-102.

[2] Aini M, Ali M, Putri B (2014) Penerapan teknik imotilisasi benih ikan Nila (Oreochromis niloticuus) menggunakan ekstrak daun Bandotan (Ageratm conyzoides) pada transportasi basah. e-Jurnal Rekayasa dan Teknologi Budidaya Perairan 2 (2): 217-225.

[3] Isnawaty N, Sidik R, Mahasri G (2015) Potensi serbuk daun pepaya untuk meningkatkan efisiensi pemanfaatan pakan, rasio efisiensi protein dan laju pertumbuhan relatif pada budidaya ikan Nila (Oreochromis niloticus). Jurnal Ilmiah Perikanan dan Kelautan 7 (2): 121-124.

[4] Amri dan Khairuman (2008) Budidaya ikan Nila secara intensif. PT Gramedia Pustaka, Jakarta.

[5] Nomoto R, Munasinghe LI, Jin, DH, Shimahara Y, Yasuda H, Nakamura A, Misawa N, Itami T, Yoshida T (2004) Lancefield Group C Streptococcus dysgalactiae Infection Responsible for Fish Mortalitas in Japan. Journal of Fish Disease 27: 679-686.

[6] Seehan B (2009) Streptococcosis in Tilapia: A more complex problem than expected? Proceeding of Managing Streptococcus in Warmwater Fish. Veracruz, Mexico 3: 9-14.

[7] Hardi EH, Sukenda, Haris E, Lusiastuti, AM (2011) Karakteristik dan patogenitas Streptococcus agalactiae tipe a-hemolitik dan non-hemolitik pada ikan Nila. Jurnal Veteriner 12 (2): 152-164.

[8] Pasnik DJ, Evans JJ, Klesius PH (2009) Fecal strings associated with Streptococcus agalactiae infection in nile tilapia, Oreochromis niloticus. The Open Veterinary Science Journal 3: 6-8.

[9] Arlyza IS (2005) Isolasi pigmen biru phycocyanin dari mikroalga Spirulina platensis. Oseanologi dan Limnologi di Indonesia 38: 79-92.

[10] Widanarni, Hadiroseyani Y, Sutanti A (2013) Pengaruh pemberian bakteri probiotik Vibrio SKT-b dengan dosis berbeda melalui Artemia terhadap pertumbuhan pascalarva udang windu Penaeus monodon. Jurnal Akuakultur Indonesia 12 (1): 86-93.

[11] Kabinawa INK (2006) Spirulina: Ganggang penggempur aneka penyakit. PT Gramedia Pustaka, Jakarta.

[12] Hamsah, Widarnani, Alimuddin, Yuhana M, Junior MZ (2018) Kinerja Pertumbuhan dan Respons Imun Larva udang Vaname yang diberi Probiotik Pseudoalteromonas piscicida dan Prebiotik Mannanoligosakarida melalui Bioenkapsulasi Artemia sp., dalam prosiding Simposium Nasional Kelautan dan Perikanan V, Universitas Hasanuddin, pp. 145-156.

[13] AOAC (1999) AOAC official methods 199.10 - Association of official analytical chemists, Maryland, USA, pp. 40-50.

[14] Park PW, RE Goins (1994) In situ preparation of fatty acid metyl ester for analysis of fatty acid composition in foods. Food Science 59 (6): 1262-1266.

[15] Muchlisin ZA, Arisa AA, Muhammadar AA, Fadli N, Arisa II, Siti-Aizah MN (2016) Growth performance and feed utilization of Keureling (Tor tambra) fingerlings fed a formulated diet with different doses of vitamin E (alphatocopherol). Archives of Polish Fisheries 23: 47-52.

[16] Budiardi T, Utomo NBP, Santoso A (2010) Pertumbuhan dan kandungan nutrisi Spirulina sp. pada foto periode yang berbeda. Jurnal Akuakultur Indonesia 9 (2): 146-156.

[17] Lovell T (1998) Nutrition and feeding of fish $2^{\text {nd }}$ ed. Kluwer Academic Pub. Springer Science p. 267. 
[18] Isnansetyo A, Kurniastuty (1995) Teknik kultur phytoplankton dan zooplankton: Pakan alami untuk pembenihan organisme laut. Penerbit Kanisius, Yogyakarta.

[19] Darwisito S, Zairin M, Sjafei DS (2008) Pemberian pakan mengandung vitamin e dan minyak ikan pada induk memperbaiki kualitas telur dan larva ikan Nila (Oreochromis niloticus). Jurnal Akuakultur Indonesia 7(1): 1-10.

[20] Williams ML, Azadi P, Lawrence ML (2003) Comparison of cellular and extracellular products expressed by virulent and attenuated strains of Edwardsiella ictaluri. Journal of Aquatic Animal Health 15: 264-273.

[21] Glaser P (2002) Genome sequencing of Streptococcus agalactiae, a pathogen causing invasive neonatal disease. Molecular Microbiology 45: 1499-1513.

[22] Woolf N (2000) Cell, tissue and disease the basis of pathology $3^{\text {th }}$ ed. WB Sanders, New York.

[23] Dwinanti SH, Sukenda, Yuhana, Lusiastuti AM (2014) Toksisitas dan imunogenitas produk ekstraseluler Streptococcus agalactiae tipe non hemolotik pada ikan Nila (Oreochromis niloticus). Jurnal Akuakultur Rawa Indonesia 2 (1): 105-116.

[24] Murray RK, Granner DK, Mayes PA, Rodwell VW (2001) Harper's biochemistry $25^{\text {th }}$ ed. Appleton and Lange Pub., England. 